\title{
Al-Chizan
}

ISSN 1907-0985, E ISSN 2442-8256

Vol. 16, No. 2, 2020, h. 349-374

DOI: https://doi.org/10.30603/am.v16i2.1881

\section{Korupsi versus Hibah dan Hadiah}

\author{
Muhammad Gazali Rahman \\ IAIN Sultan Amai Gorontalo \\ Email: gazali.iain@gmail.com
}

\begin{abstract}
This study discusses the issue of corruption that occurs in human life. However, the problem is how the grants and gifts given to certain parties are categorized as corruption. This research is library research which is analyzed with a qualitative approach with national law and Islamic law perspectives. The results showed that from the point of view of Islamic law, people's insights were very limited to the issue of bribes and rewards. Some people think that bribery is not a crime, but only a small mistake. Some others, even so, that bribes are forbidden, but they do not care about the prohibition, let alone because they get the benefits. On the other hand, society perceives the bribe as a gift or a token of gratitude. Some even think of it as money for the help someone has given, so they don't feel it as a mistake or even a crime.
\end{abstract}

Keywords: Corruption, Grants, Rewards

\section{Corruption versus Grants and Rewards}

\begin{abstract}
Abstrak: Penelitian ini membahas isu korupsi yang marak terjadi dalam kehidupan manusia. Namun yang menjadi permasalahan adalah bagaimana hibah dan hadiah yang diberikan kepada pihak-pihak tertentu, apakah dikategorikan korupsi. Penelitian ini adalah penelitian kepustakaan dengan dianalisis dengan dekriptif kualitatif dengan pendekatan hukum nasional dan hukum Islam. Hasil penelitian menunjukkan bahwa dari sudut pandang hukum Islam, wawasan masyarakat sangat terbatas mengenai masalah sogok dan hadiah. Sebagian masyarakat beranggapan bahwa sogok bukan sebuah kejahatan, tetapi hanya kesalahan kecil. Sebagian lain, walaupun mengetahui bahwa sogok adalah terlarang, namun mereka tidak peduli dengan larangan tersebut, apalagi karena terpengaruh dengan keuntungan yang didapatkan. Di pihak lain, masyarakat menganggap sogok itu sebagai hadiah atau tanda terima kasih. Bahkan ada yang beranggapan sebagai uang jasa atas bantuan yang telah diberikan seseorang, sehingga mereka tidak merasakan hal itu sebagai sebuah kesalahan atau pelanggaran apalagi kejahatan.
\end{abstract}

Kata Kunci: Korupsi, Hibah, Hadiah 


\section{A. Pendahuluan}

Salah satu isu krusial dewasa ini yang menjadi perbincangan publik, terutama yang marak dilansir oleh media cetak dan elekteronik adalah masalah korupsi. Masalah ini merupakan persoalan moral dan budaya yang tumbuh dan berkembang di hampir semua sistem birokrasi suatu lembaga, baik sosial, ekonomi, lebih-lebih politik. Korupsi di Indonesia bukan lagi merupakan sebuah gejala, melainkan sudah merupakan fakta yang terkenal di mana-mana. Kini, setelah rezim Soeharto tumbang, praktek Korupsi, Kolusi dan Nepotisme (KKN) terbukti sudah menjadi "tradisi dan budaya" yang telah meluas, berurat-berakar dan menggurita dalam jaringan sistem politik di Indonesia, mulai dari pusat hingga lapisan kekuasaan yang paling bawah.

Di antara penyebab korupsi adalah tradisi/kebiasaan memberi hadiah kepada atasan, ketidakberdayaan manajemen (termasuk di dalamnya belum efektifnya makanisme pengawasan), tekanan kebutuhan ekonomi yang makin keras. dan mentalitas pelaku yang rusak. ${ }^{1}$ Dari perspektif moral keagamaan, penyebab yang terakhir merupakan persoalan yang langsung berkaitan dengan individu pelaku, sehingga akar persoalannya dan antisipasi pemberantasannya perlu dimulai dari individu-individu yang bersangkutan.

Salah satu yang terpenting dari penyebab terjadinya korupsi adalah ketidakjujuran pada diri seseorang. Ketidakjujuran sebenarnya bukanlah sikap yang bisa terjadi secara kebetulan, namun memiliki latarbelakang mengapa seseorang berperilaku tidak jujur dalam hidupnya. Faktor-faktor tersebut sebagaimana dipaparkan oleh Yunahar Ilyas, meliputi individu, keluarga, sekolahan, masyarakat, dan bahkan bangsa, di mana semua faktor tersebut sama-sama memiliki potensi untuk membentuk kepribadian yang tidak jujur. ${ }^{2}$

Praktek korupsi sangat melanggar kaidah kejujuran, juga melanggar hukum yang berlaku, serta menurunkan kewibawaan negara dan pemerintah, lagi pula mengakibatkan high cost economy yang menaikkan harga produk dan menurunkan

\footnotetext{
${ }^{1}$ Baharuddin Lopa, "Korupsi: Sebab-Sebabnya dan Penanggulangannya", Prisma, Nomor 3 Tahun 1996; 30-33.

${ }^{2}$ Yunahar Ilyas, dkk., Korupsi dalam Perspektif Agama-agama (Yogyakarta: Lembaga Penelitian dan Pengembangan Pendidikan, 2004), 61.
} 
daya saing. ${ }^{3}$ Semua demi keuntungan untuk memperkaya diri pribadi dan atau keluarga. Akibatnya, timbul kesenjangan ekonomi dan sosial antara golongan kaya raya dan berkuasa di level atas, dan golongan wong cilik yang sehari-hari harus bekerja keras untuk mempertahankan hidup yang layak di level bawah.

Oleh karena itu, dari aspek normatif jelas bahwa korupsi menyalahi etika agama, dan tentu saja menimbulkan berbagai implikasi negatif bagi pelakunya dan orang lain. Di sisi lain, terutama bila ditinjau dari aspek tujuan penetapan hukum dalam Islam, maka tentu saja praktek korupsi tersebut sangat menyalahi maqāshid alsyari'ah. Namun perlu dicermati adanya persepsi di masyarakat terkait pemberian, baik itu hibah maupun hadiah kepada pejabat negara atau pihak-pihak tertentu yang dianggap sebagai bentuk KKN tersebut.

\section{B. Korupsi:Pengertian, Bentuk, Ciri-Ciri dan Faktor Penyebabnya}

Kata "korupsi” berasal dari kata Latin “corruptus" yang berarti sesuatu yang rusak atau hancur. Dalam pemakaian sehari-hari dalam bahasa-bahasa modern Eropa, seperti bahasa Inggris, kata "korupsi" dapat digunakan untuk menyebut kerusakan fisik seperti frasa "a corrupt manuscript" (naskah yang rusak) dan dapat juga untuk menyebut kerusakan tingkah laku atau tidak bermoral (immoral) atau tidak jujur atau tidak dapat dipercaya (dishonest). Selain itu korupsi juga berarti tidak bersih (impure). ${ }^{4}$

Pada kajian-kajian mengenai korupsi, ada berbagai definisi yang dikemukakan oleh para ahli menyangkut terminologi korupsi. Syed Hussein Alatas menegaskan bahwa "esensi korupsi adalah pencurian melalui penipuan dalam situasi yang mengkhianati kepercayaan". 5 Dalam Webster's Third New International Dictionary, korupsi didefinisikan sebagai “ajakan (dari seseorang pejabat publik) dengan

\footnotetext{
${ }^{3}$ Robert Klitgaard, Controlling Corruption, terj. Hermoyo, Membasmi Korupsi, Ed. 2 (Cet. II: Jakarta Yayasan Obor Indonesia, 2001), xiii.

${ }^{4}$ Hornby, Oxford Advanced Learner's Dictionary (Oxford: Oxford University Press, 1999), 266.

${ }^{5}$ Syed Hussien Alatas, Corruption Its Nature, Causes and Functions, terj. Nitwono, Korupsi: Sifat, Sebab dan Fungsi (Jakarta: LP3ES, 1997), viii.
} 
pertimbangan-pertimbangan yang tidak semestinya untuk melakukan pelanggaran tugas". 6

Menurut Subekti, korupsi adalah suatu tindak pidana yang memperkaya diri sendiri yang secara langsung merugikan keuangan atau perekonomian negara. ${ }^{7}$ Sedangkan Transparency Internasional mendefinisikan korupsi sebagai penyalahgunaan kekuasaan dan kepercayaan publik untuk keuntungan pribadi. ${ }^{8}$ Dalam Kamus Ilmiah Populer, korupsi mengandung pengertian kecurangan, penyelewengan/ penyalahgunaan jabatan untuk kepentingan diri sendiri, pemalsuan. ${ }^{9}$

Menurut Robert Klitgaard, korupsi meliputi tindakan berupa: (1) memungut uang atas pelayanan yang sudah seharusnya diberikan; (2) menggunakan wewenang untuk mencapai tujuan yang tidak sah; dan (3) tidak melaksanakan tugas karena lalai atau lupa. ${ }^{10}$ Bank Dunia menganut definisi klasik yang singkat tapi luas cakupannya yang memandang korupsi sebagai the abuse of public office for private gain 'penyalahgunaan jabatan publik untuk memperoleh keuntungan pribadi'. ${ }^{11}$

Dengan demikian, unsur pokok korupsi tersebut sesungguhnya tercermin adanya: (1) perbuatan menyimpang dari norma; (2) perbuatan itu menimbulkan kerugian kepada negara atau masyarakat meskipun tidak selalu berupa kerugian finansial, misalnya kerugian dalam bentuk buruknya pelayanan umum atau tidak berjalannya sistem hukum; (3) adalah penyalahgunaan wewenang.

Alatas mengungkapkan adanya enam ciri tindak korupsi: (1) adanya pengkhianatan kepercayaan; (2) keserbarahasiaan; (3) mengandung penipuan terhadap badan publik atau masyarakat; (4) dengan sengaja melalaikan kepentingan umum untuk kepentingan khusus; (5) diselubungi dengan bentuk-bentuk pengesahan hukum;

\footnotetext{
${ }^{6}$ Syamsul Anwar, "Sejarah Korupsi dan Perlawanan Terhadapnya di Zaman Awal Islam: Perspektif Studi Hadis”, Hermenia, Volume 4, Nomor 1, Januari-Juni 2005; 108.

${ }^{7}$ Hasyim Muzadi dan Benediktus, Menuju Indonesia Baru (Malang: Bayu Media Publishing, 2004), 106.

${ }^{8}$ IGM. Nurdjana, dkk., Korupsi dan Illegal Logging dalam Sistem Desentralisasi (Yogyakarta: Pustaka Pelajar, 2005), 24-25.

${ }^{9}$ Ibid., 21.

${ }^{10}$ Robert Klitgaard, dkk., Penuntun Pemberantasan Korupsi dalam Pemerintahan Daerah, alih bahasa Masri Maris (Jakarta: Yayasan Obor dan Partnership for Government Reform di Indonesia, 2002), 3 .

${ }^{11}$ Syamsul Anwar, "Sejarah Korupsi dan Perlawanan,” 108.
} 
(6) terpusatnya korupsi pada mereka yang menghendaki keputusan pasti dan mereka yang dapat mempengaruhinya. ${ }^{12}$

Tindak korupsi menurut keenam ciri tersebut, tampaknya cukup kompleks, interrelated, bahkan intricate. Ada percampuran antara pengkhianatan amanah (moral), perlindungan hak-hak asasi manusia (HAM), mendahulukan kemaslahatan umum (kepentingan publik), yang berhadapan langsung dengan kecenderungan manusia untuk memenuhi kebutuhan pribadi (vested interest). Dengan demikian, wilayah birokrasi, kekuasaan (power), hukum, moral, psikologi, sosiologi, kultur, campur baur di situ. Mengingat kompleknya persoalan korupsi, maka pendidikan agama anti korupsi paling tidak mencakup item-item tersebut. Sekadar memperjelas bagaimana rumitnya persoalan di lapangan dapat diilustrasikan sebagai berikut:

Pejabat pemerintah selaku penyelenggara negara dalam melayani masyarakat (urusan publik) dan melaksanakan pembangunan selalu membutuhkan bantuan pihak lain (rekanan/pemborong) untuk memfasilitasi seperti instalasi listrik, air, telekomunikasi, pembangunan gedung publik, jalan, jembatan dan konstruksi bangunan lainnya hingga pada bentuk jasa layanan informasi, penelitian, data survey serta konsultasi keahlian. Ini semua dilakukan melalui mekanisme pengadaan barang dan jasa pemerintah (government procurement) dimana segala ketentuannya telah diatur dalam Keputusan Presiden Nomor 61 Tahun 2004 jo. Keputusan Presiden Nomor 80 Tahun 2003 serta diatur pula dalam berbagai undang-undang seperti Undang-Undang Nomor 18 Tahun 1999 tentang Jasa Konstruksi dan juga Undang-Undang Nomor 5 Tahun 1999 tentang Anti Monopoli yang mengharuskan proses tersebut dilakukan dengan menjunjung tinggi prinsip efisiensi, efektivitas, transparansi, persaingan sehat, akuntabel dan adil bagi semua pihak.

Mekanisme pengadaan barang dan jasa pemerintahan ini sesungguhnya sudah cukup ketat prosedurnya. Dari sistem pelelangan umum, pelelangan terbatas atau penunjukan langsung. Itupun masih ditambah dengan model penyeleksian peserta

\footnotetext{
${ }^{12}$ Syed Hussien Alatas, The Sosiologi of Corruption, terj. Al Ghozie Usman, Sosiologi Korupsi: Sebuah Penjelajahan dengan Data Kontemporer (Jakarta: LP3ES, 1995), 13.
} 
dengan cara prakualifikasi atau pasca kualifikasi dengan metode satu sampul, metode dua sampul atau metode dua tahap. ${ }^{13}$

Berbagai cara yang umum dilakukan para koruptor untuk mengambil uang negara. Pertama adalah "main mata" antara pejabat pemerintah (Birokrasi) dengan rekanan untuk merekayasa hasil pemenang tender, selanjutnya rekanan mengirim "amplop" pada birokrat melalui rekanan saudara, anak, istri, bahkan mungkin tetangga (teknik penyuapan). Kedua, dengan menaikkan nilai-nilai barang atau jasa (mark-up), harga per-unit yang seharusnya 1000 dinaikkan menjadi 1200 dan akhirnya kelebihan harga digunakan untuk dibagi bersama antara mereka (aspek moral; ketidakjujuran).

Ketiga, para birokrat tadi (atau saudara atau temannya) menyamar menjadi perantara alias makelar dari proyek yang dia pimpin sendiri. Jelas saja mereka punya anggapan, makelar 'kan harus dapat uang komisi (sosiologi kekerabatan). Keempat, cara yang paling kasar digunakan yaitu para birokrat berlakon sebagai pengguna sekaligus penyedia (rekanan) proyek, sejak dari batu bata, pasir, semen, besi, genteng, peralatan listrik dan seterusnya. Tentu saja tak ada yang bisa menghalangi kalau dia mau berbuat seperti itu (keserakahan).

Dengan ilustrasi betapa kompleks dan rumitnya persoalan di lapangan, maka Alatas kemudian mempertajam pisau bedah seluk beluknya (know-how) korupsi lebih dalam dan menjelaskan adanya 7 (tujuh) jenis korupsi:

1) Korupsi transaktif, yaitu jenis korupsi yang berwujud adanya kesepakatan timbal balik antara pihak-pihak bersangkutan guna mengupayakan keuntungan bersama. Korupsi jenis ini bisanya terjadi antara usahawan dengan pejabat pemerintah atau anggota masyarakat dengan pemerintah.

2) Korupsi ekstortif (memeras), yaitu bentuk korupsi dimana pihak pemberi dipaksa melakukan penyuapan guna mencegah kerugian yang akan mengancam diri, kepentingan, orang-orang atau hal-hal yang lain baginya.

3) Korupsi defensif, yaitu korupsi yang dilakukan oleh pelaku korban korupsi pemerasan.

\footnotetext{
${ }^{13}$ Meskipun tidak menangani secara langsung, penulis sebagai Rektor memahami betul betapa rumit dan melelahkannya proses dan prosedur yang harus dilakukan panitia lelang ketika melakukan pelelangan beberapa item pekerjaan yang didanai oleh Islamic Development Bank (IDB).
} 
4) Korupsi investif, yaitu korupsi berwujud pemberian sesuatu ada kaitan langsung dengan keuntungan tertentu, selain keuntungan yang dibayangkan dimasa depan.

5) Korupsi nepotistik (perkerabatan), yaitu korupsi berupa penunjukan tidak sah terhadap teman atau kerabat untuk menempati posisi dalam pemerintahan atau memberi perlakuan istimewa kepada mereka secara bertentangan dengan norma yang berlaku.

6) Korupsi otogenik, yaitu yang dilakukan sendirian tanpa melibatkan orang lain, misalnya membuat laporan belanja yang tidak benar.

7) Korupsi suportif(dukungan), yaitu tindakan yang dimaksudkan untuk melindungi atau memperkuat korupsi yang sudah ada.

8) Korupsi legal, yaitu suatu kebijakan yang secara hukum adalah sah karena sesuai dengan ketentuan peraturan yang berlaku, namun sesungguhnya pada dasarnya merupakan suatu korupsi bila dilihat dari sudut visi penyelenggaraan kepemerintahan yang baik. Termasuk dalam kategori ini adalah apa yang sering dengan korupsi demokratis, yaitu kebijakan yang disahkan oleh legislatif, namun bertentangan dengan visi yang benar dari kepemerintahan yang baik (good governance). Misalnya penganggaran rumah dinas pejabat yang jauh lebih besar dari anggaran pembangunan gedung sekolah dasar. ${ }^{14}$

Lebih dari itu, Alatas juga menjabarkan beberapa ciri dari korupsi sebagai berikut:

1) Suatu pengkhianatan terhadap kepercayaan;

2) Penipuan terhadap badan pemerintah, lembaga swasta atau masyarakat pada umumnya;

3) Dengan sengaja mengabaikan kepentingan umum demi kepentingan khusus, pribadi atau golongan;

4) Dilakukan dengan rahasia, kecuali dalam keadaan di mana orang-orang yang berkuasa atau bawahannya menganggapnya tidak perlu;

5) Melibatkan lebih dari satu orang atau pihak;

6) Adanya kewajiban dan keuntungan bersama, dalam bentuk uang atau lainnya;

\footnotetext{
${ }^{14}$ Alatas, Korupsi: Sifat, ix-x; Lihat juga Alatas, Sosiologi Korupsi, 109.
} 
7) Adanya usaha untuk menutupi perbuatan korup dalam bentuk-bentuk pengesahan hukum.

8) Menunjukkan fungsi ganda yang kontradiktif pada mereka yang melakukan tindakan korupsi. ${ }^{15}$

Beberapa ciri korupsi yang disebutkan di atas, ciri yang terakhir adalah ciri yang membedakan korupsi dari beberapa jenis kejatahan lainnya. Terkait dengan ciri ini, ketika seorang pejabat menerima suap untuk mengeluarkan izin usaha, tindakan pemberian izin yang sesuai dengan peraturan dan tata cara pengeluarannya adalah bagian dari fungsi jabatan yang dimilikinya. Penerimaan uang suap sebagai kepentingan pribadi dapat dilakukan melalui fungsi jabatan tersebut. Dalam kondisi itu, seorang pejabat bertindak dalam kapasitas ganda yang satu sama lain saling bertentangan. Oleh karena itu, menurut Alatas, esensi korupsi adalah pencurian melalui penipuan dalam situasi yang mengkhianati kepercayaan. ${ }^{16}$

Istilah "korupsi" dalam bahasa Arab bisa disebut al-fasad, risywah, dan lebih spesifik, ikhtilas atau nahb al-amwal al-'ammah. Namun, istilah "korupsi" lebih tepat digunakan untuk kata 'ghulül' yang berasal dari ghalla-yaghullu yang berarti 'berkhianat' (khāna-yakhūnu- khiyānatan). Dengan begitu, kata ghulūl lebih bersifat umum. Selain itu, dalam literatur Islam, ghulül juga berarti pencurian (dari harta ghanimah). Al-Qurțuby menjelaskan, setiap orang yang berkhianat mengenai sesuatu secara sembunyi berarti telah melakukan ghulūl. ${ }^{17}$ Dalam studi hadis, kata ghulūl pada asalnya bermakna khianat dalam urusan harta rampasan perang, atau mencuri sesuatu dari harta rampasan perang sebelum dibagikan. Kemudian, kata ini digunakan untuk setiap perbuatan khianat dalam suatu urusan secara sembunyi-sembunyi. ${ }^{18}$ Jadi, kata ghulūl di atas, secara umum digunakan untuk setiap pengambilan harta oleh seseorang secara khianat, atau tidak dibenarkan dalam tugas yang diamanahkan kepadanya.

\footnotetext{
${ }^{15}$ Alatas, Korupsi: Sifat, viii.

${ }^{16}$ Ibid., viii.

${ }^{17} \mathrm{Abū}$ 'Abdillāh Muhammad bin Ahmad al-Qurțuby, Al-Jami' li Ahkām al-Qur'ān, Juz IV (AlMisr: Dār al-Kutub al-Mișriyah, 1967), 255.

${ }^{18} \mathrm{Abu}$ Isa Muhammad bin Isa al-Tirmizy, Sunan al-Tirmizy (Bairut: Dār al-Kutub alIslamiyyah, 2002), 106.
} 
Olehnya itu, korupsi dalam perspektif hukum Islam mempunyai makna luas, yaitu mencakup segala bentuk manipulasi, pemerasan, kecurangan, penyuapan, pencurian, dan nepotisme, dan tidak terbatas pada kerugian negara saja.

Terkait dengan itu, beberapa faktor yang menjadi penyebab terjadinya korupsi antara lain:

\section{1) Faktor Individu}

Seseorang yang terlibat dalam tindak korupsi biasanya tidak memiliki atau kurang memahami ajaran-ajaran moral agama, atau memahami terhadap ajaran agama, namun kurang memiliki kesadaran dalam dirinya untuk melaksanakan nilai-nilai keagamaannya dalam kehidupan sehari-hari. Pengetahuan tentang agama belum menjadi sebuah keimanan dalam dirinya sehingga tidak terwujud adanya singkronisasi antara pengertian atau pemahaman dengan pengamalannya.

\section{2) Faktor Keluarga}

Keluarga menjadi salah satu faktor seseorang kurang memperhatikan nilai-nilai kejujuran dalam dirinya. Kondisi keluarga yang cenderung meremehkan nilai-nilai kejujuran akan mempengaruhi sikap anggota keluarga tersebut. Faktor lain adalah kondisi keluarga yang mendesak seseorang untuk melakukan tindak korupsi. Ketika kondisi ekonomi dan kebutuhan yang didasarkan pada ketidakpuasan hidup telah merasuki pikiran dan kondisi seseorang, maka dia cenderung akan menyalahgunakan wewenangnya untuk memuaskan diri dan keluarganya.

\section{3) Faktor Sekolah}

Keteladanan dari guru adalah salah satu faktor kunci terhadap pembentukan siswa-siswa dalam bertindak jujur terhadap orang lain. Sistem "salah" di sekolah seringkali menjadi faktor pembentukan pada sikap ketidakjujuran dari para siswa, seperti sistem yang tidak transparan dalam pemungutan biaya. Pengalaman para siswa ini akan mempengaruhi sikap mereka di luar sekolah, pada saat mereka sudah lulus bahkan ketika menjadi pejabat dalam pemerintahan atau swasta akan cenderung menyalahgunakan wewenangnya untuk melakukan tindak korupsi. 
4) Faktor Masyarakat

Masyarakat yang dimaksud di sini adalah lingkungan pergaulan sehari-hari. Terbentuknya interaksi sosial dengan masyarakat dalam semua level yang ada di dalamnya sangat mendukung karakter kepribadian seseorang: jika interaksi tersebut dibentuk atas dasar keimanan dan keagamaan yang kokoh, maka akan membentuk kepribadian yang jujur, namun jika masyarakat terbentuk oleh kebiasaan yang melenceng dari nilai-nilai luhur agama, seperti ketidakjujuran, maka ketidakjujuran dan selanjutnya perilaku korupsi akan terbentuk dengan mudah dalam dirinya.

\section{5) Faktor Negara}

Sebuah sistem pemerintahan yang tidak dibangun melalui nilai-nilai luhur agama akan berdampak pada krisis moral bangsa. Krisis ini akan berakibat pada terjadinya krisis di beberapa bidang lainnya, yakni krisis ekonomi, politik, dan kebudayaan. Kondisi seacam ini akan mewabah pada setiap level kehidupan masyarakat sehingga tradisi tidak jujur terus mengakar dan mengubah masyarakat menjadi masyarakat yang korup.

Mencermati hal di atas, korupsi terjadi selain karena sistem dan struktur juga diakibatkan oleh kultur. Oleh sebab itu, memperbaiki kultur harus dengan pendekatan kultur pula, tidak cukup dengan pendekatan hukum saja. Tegasnya, dengan memahami gejala tersebut, upaya-upaya yang dapat dilakukan antara lain:

1) Melakukan penguatan dakwah kultural dan kampanye anti korupsi mulai dari tingkat masyarakat sampai pada tingkat lembaga pemerintahan;

2) Berkerjasama dengan Pemerintah Daerah dalam melakoni pemberantasan korupsi;

3) Bekerjasama dengan Lembaga Swadaya Masyarakat (LSM) atau organisasi masyarakat (ormas) lainnya yang concent dalam pemberantasan korupsi;

4) Membentuk lembaga khusus yang membidangi masalah ini;

5) Menjadikan gerakan anti korupsi sebagai tema besar dalam setiap agenda aksi.

Jika dilacak dalam sejarah Islam, tindakan korupsi sebenarnya pernah terjadi pada masa Rasulullah saw., yaitu pada masa beliau berada di Madinah, di mana pada masa itu masyarakat Muslim telah mengalami satu tatanan masyarakat yang lebih 
terorganisir. Segala sektor kehidupan negara Madinah telah mengalami kemajuan. Setiap sektor dipegang oleh sahabat yang mendapat kepercayaan. Kondisi semacam ini tentu juga membentuk satu manajemen keuangan Negara, yaitu Anggaran Pendapatan dan Belanja Negara (APBN) yang lebih baik.

\section{Korupsi dalam Perspektif Hukum Islam}

Beberapa riwayat disebutkan bahwa tindakan korupsi muncul pada periode Madinah awal. Al-Ṭabary meriwayatkan bahwa pada masa perang Badar, yang terjadi pada tahun ke-2 Hijriyah, telah terjadi tindakan korupsi, yaitu hilangnya sehelai beludru merah yang dihasilkan dari rampasan perang terhadap kaum musyrikin. ${ }^{19}$

Kasus raibnya beludru merah ${ }^{20}$ ini kemudian menimbulkan kerisauan di kalangan para sahabat saat itu. Salah seorang sahabat yang saat itu sedang bersama Nabi Muhammad saw. mengira bahwa yang mengambilnya adalah Nabi sendiri. Adanya sangkaan buruk terhadap Nabi inilah kemudian ditanggapi dengan turunnya firman Allah swt.:
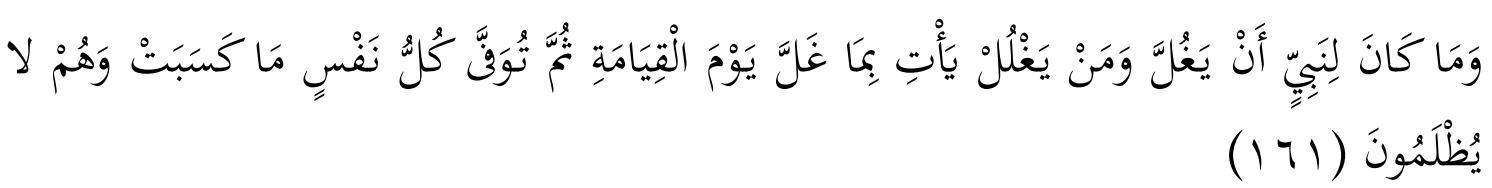

Terjemahnya:

Dan tidak mungkin seorang nabi berkhianat (dalam urusan harta rampasan perang). Barangsiapa berkhianat, niscaya pada hari Kiamat dia akan datang membawa apa yang dikhianatkannya itu. Kemudian setiap orang akan diberi balasan yang sempurna sesuai dengan apa yang dilakukannya, dan mereka tidak dizalimi (QS Āli 'Imrān/3: 161). ${ }^{21}$

Meski begitu, terdapat pula keterangan lain yang mengaitkan turunnya ayat di atas dengan peristiwa perang Uhud, yang terjadi pada tahun ke-3 Hijriyah. ${ }^{22}$ Keterangan ini direkam dalam hadis Nabi saw.:

\footnotetext{
${ }^{19}$ Al-Qurțuby, Al-Jami' li Ahkām al-Qur'ān, Juz IV, 255; Abū Ja'far Muhammad bin Jarìr alTabari, Jami' al-Bayān 'an Ta'wil Āyät al-Qur'ān, Juz VI (Bairut: Dār al-Fikr, 1405 H), 154-156.

${ }^{20}$ Dalam sebuah riwayat dinyatakan bahwa barang yang hilang tersebut adalah berupa pedang. Lihat Al-Qurțuby, Al-Jami' li Ahkām al-Qur'ān, 255.

${ }^{21}$ Kementerian Agama RI., Ummul Mukminin: Al-Qur'an dan Terjemahan untuk Wanita (Jakarta Selatan: Penerbit Wali, 2010), 71.

${ }^{22}$ Al-Wahidy, Asbāb al-Nuzūl (Bairut: Dār Fikr li al-Ṭiba'ah wa al-Nasyr, 1991), 84-85.
} 


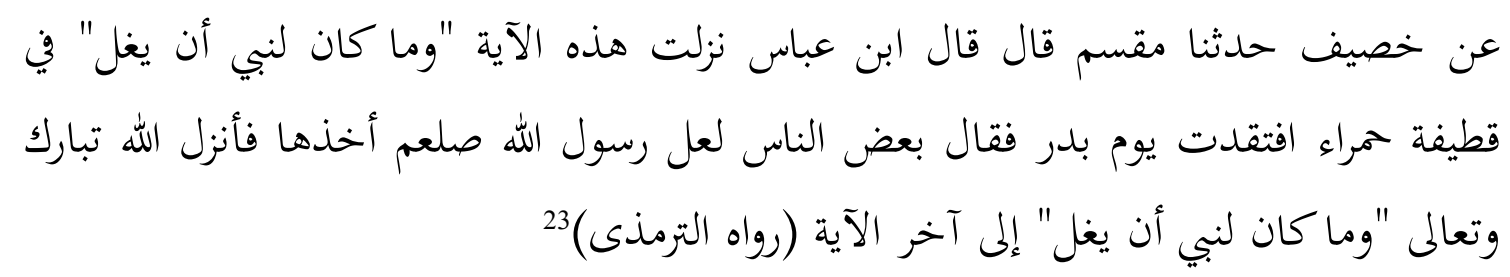

Artinya:

Dari Khusaif (dilapokan bahwa dia berkata): Miqsam telah menyampaikan kepada kami seraya berkata: Ibnu 'Abbās mengatakan: Ayat ini "wa mā kāna li nabiyyin an yaghulla" turun berkenaan kasus beludru merah yang hilang sewaktu Perang Badar. Beberapa orang mengatakan: Barangkali Rasulullah saw. mengambilnya, kemudian Allah menurunkan ayat, "wa mā kāna li nabiyyin an yaghulla" hingga akhir ayat (HR al-Tirmizy).

Para ulama menghubungkan isu korupsi yang terjadi pada masa perang Uhud, di mana strategi perang yang diterapkan Nabi adalah menempatkan pasukan pemanah di atas bukit di belakang pasukan Rasulullah untuk melindungi beliau. Strategi ini berhasil dan pasukan kaum muslimin mencapai kemenangan. Namun kemudian barisan dari pasukan muslimin yang berada di bawah menjadi kucar kacir untuk berebut harta rampasan perang, sehingga membuat pasukan pemanah yang berada di atas bukit turun. Akibatnya, pasukan kaum muslimin mengalami kekalahan dalam perang (Uhud) tersebut. Pada saat pasukan pemanah turun ke bawah, Nabi bersabda: "Sebenarnya kalian pasti mengira bahwa kami melakukan ghulūl". ${ }^{24}$ Anggapan tersebut disanggah dengan turunnya QS Āli 'Imrān/3: 161 tersebut.

Al-Ṭabary menafsirkan QS Āli 'Imrān/3: 161 ini dengan, "bukanlah sifat Nabi untuk melakukan ghulūl, dan orang yang melakukan ghulūl itu bukan Nabi, ${ }^{25}$ sehingga berdasarkan ayat tersebut dapat dipahami tentang pengertian ghulül itu sendiri, bahwa ghulūl adalah kebijakan dalam pembagian harta rampasan perang yang tidak adil, atau menyimpang dari ketentuan yang ada. Dengan kata lain, ghulül, yang disebut korupsi itu adalah kebijakan yang dibuat, bukan berdasarkan aturan yang semestinya.

\footnotetext{
${ }^{23}$ Al-Tirmizy, Sunan al-Tirmizy, hadis nomor 3009.

${ }^{24}$ Jalaluddin 'Abdurrahman bin Abī Bakr al-Suyūty, Lubāb al-Nuqūl fí Asbāb al-Nuzūl (Bairut: Dār al-Ihyā' al-'Ulūm, t.th.), 228.

${ }^{25} \mathrm{Abū}$ Ja'far Muhammad bin Jarir al-Ṭabari, Jami' al-Bayān 'an Ta'wil Āyāt al-Qur'ān, VI (Bairut: Dār al-Fikr, 1405 H), 157.
} 
Al-Tirmizy dalam riwayatnya yang lain juga menjelaskan:

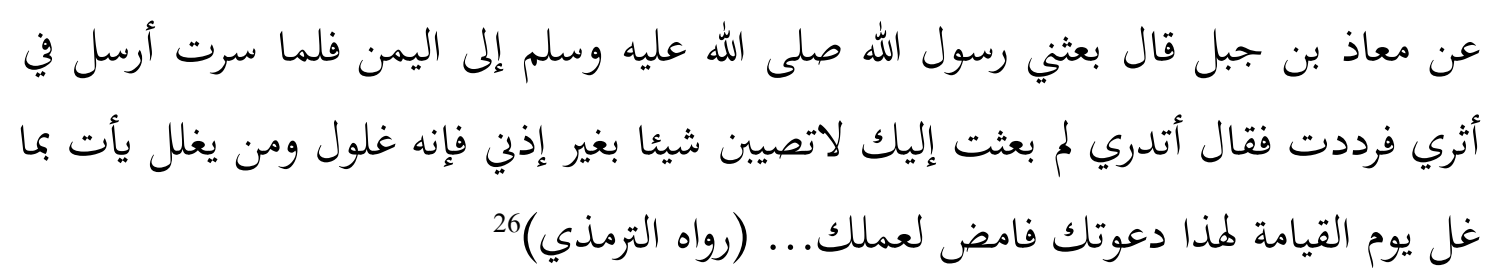

Artinya:

Dari Mu'āz bin Jabal diriwayatkan bahwa dia berkata: Rasulullah mengutus saya ke Yaman. Ketika saya baru berangkat, beliau mengirim seseorang untuk memanggil saya kembali, maka saya pun kembali. Kemudian beliau berkata: Apakah engkau tahu mengapa saya mengirim orang untuk menyuruhmu kembali? Janganlah kamu mengambil sesuatu apapun tanpa izin dariku, karena hal itu adalah ghulūl (korupsi), dan barangsiapa melakukan ghulūl, maka dia akan membawa barang yang di-ghulul itu kelak di hari kiamat. Untuk itulah saya memanggilmu. Sekarang berangkatlah untuk tugasmu... (HR al-Tirmizy).

Hadis tersebut menjelaskan bahwa Nabi berpesan kepada Mu'āz bin Jabal yang akan diutus ke wilayah Syām agar tidak sembarang mengambil atau memungut sesuatu tanpa seizin dari Nabi, sebab hal itu rawan akan terjadi prilaku korupsi. Secara implisit, dari hadis tersebut juga dapat dipahami bahwa bentuk korupsi (ghulūi) bersifat lebih umum, dan tidak hanya terbatas pada harta rampasan perang sebagaimana dijelaskan dalam hadis pertama. Hadis itu pun mengisyaratkan bahwa bentuk korupsi terkait dengan harta kekayaan negara (masyarakat) yang diambil secara melanggar hukum oleh seorang pejabat.

Korupsi dalam terminologi fikih Islam dapat dikategorikan sebagai kejahatan (jarimah) terhadap amanah. Korupsi identik dengan risywah (suap) dan al-tajawwuz fi isti'māl al-haq (menyalahgunakan wewenang). Jika dilakukan secara sembunyisembunyi disebut pencurian (sariqah) dan jika dilakukan secara terang-terangan disebut sebagai perampokan (al-nahb/hirabah). Korupsi termasuk kejahatan terhadap harta benda manusia (akl amwāl al-nās bi al-bațil) dan secara esensial mirip dengan ghulūl, yaitu pengkhianatan terhadap amanah dalam pengelolaan harta rampasan perang (ghanimah).Ghulul jelas-jelas diharamkan dalam Alquran dengan ancaman

\section{Umarä, 621 .}

${ }^{26}$ Al-Tirmizy, Sunan al-Tirmizy, Juz III, hadis nomor 1335, dalam bab Mā Jā’a fỉ Hadāyā al- 
bahwa pelakunya akan membawa serta barang yang dikorupsinya sebagai pertanggungjawaban di akhirat.

Tindakan korupsi sedikitnya terdapat tiga kejahatan, yaitu: pertama, kejahatan yang berdampak pada hilangnya uang negara sehingga tindakan korupsi yang akut akan menyebabkan hilangnya hajat hidup orang banyak, memperlebar kesenjangan sosialekonomi, dan menghilangkan keadilan. Kedua, korupsi dapat menghilangkan hak hidup warga negara dan regulasi keuangan negara. Negara yang korup akan menyebabkan lahirnya kemiskinan dan kebodohan. Ketiga, kejahatan korupsi menggerogoti kehormatan dan keselamatan generasi penerus. Temuan bahwa Indonesia merupakan negara terkorup menyebabkan harga diri sebagai bangsa menjadi ternoda. Berdasarkan hal tersebut, maka korupsi telah bertentangan dengan tujuan syariah (maqāsid alsyari' $\left.{ }^{\prime} a h\right)$.

Lebih dari itu, hukum Islam memandang korupsi sebagai perilaku hirabah. Hirabah adalah aksi seseorang atau sekelompok orang dalam negara untuk melakukan kekacauan, pembunuhan, perampasan harta, yang secara terang-terangan mengganggu dan menentang peraturan yang berlaku, perikemanusiaan, dan agama. Hirabah merupakan salah satu bentuk jarimah hudud, yaitu tindak pidana yang jenis, jumlah, dan hukumannya ditentukan oleh syari'at. Hirabah disebut juga oleh ahli fikih (fuqaha') sebagai qat'u al-tariq (menyamun) atau al-sariqah al-kubra (pencurian besar). Ulama fikih menyebut hirabah sebagai al-sariqah al-kubra, karena hirabah itu merupakah upaya mendapatkan harta dalam jumlah besar dengan akibat yang dapat menyebabkan kematian atau terganggunya keamanan dan ketertiban. Mayoritas ulama memang mempersyaratkan hirabah dengan tindakan-tindakan kekerasan untuk merampas harta, mengganggu keamanan, dan mengancam nyawa manusia, tetapi kekerasan dan gangguan keamanan yang dimaksud tidak dijelaskan lebih detail. Korupsi disamakan hirabah karena ia dapat merusak, seperti hirabah mengganggu stabilitas negara dan mengancam hidup orang banyak akibat kekayaan negara yang digerogotinya.

Pelaku hirabah dituntut hukuman yang sangat berat dalam Islam, karena ia adalah salah satu bentuk pidana hudud yang langsung ditentukan oleh nash Al-Qur'an. 
Apabila tindak pidana ini telah terbukti secara meyakinkan di sidang pengadilan, maka hakim dapat mengeksekusi hukuman yang telah ditentukan Allah swt tersebut tanpa boleh diubah, ditambah, maupun dikurangi, karena ini adalah hak Allah swt.

Ayat Alquran yang menunjukkan hukuman bagi pelaku hirabah tersebut adalah firman Allah swt.:

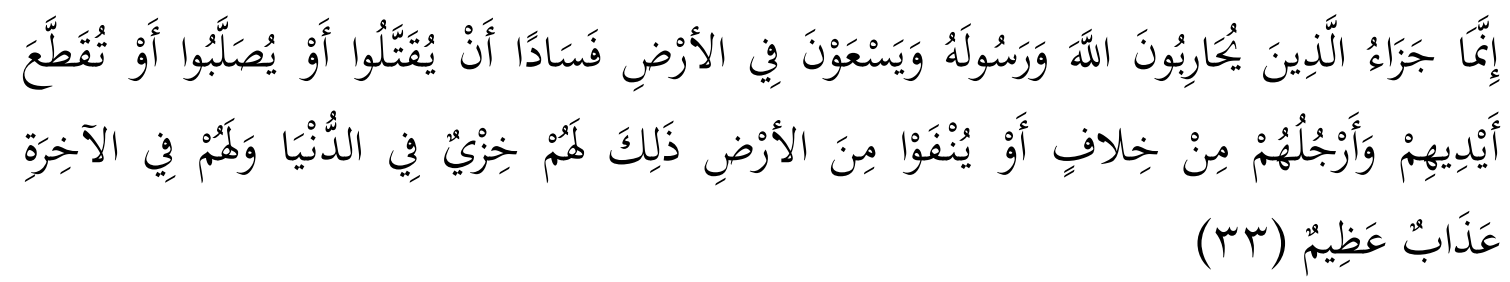

Terjemahnya:

Hukuman bagi orang-orang yang memerangi Allah dan Rasul-Nya dan membuat kerusakan di atas bumi, hanyalah dibunuh atau disalib, atau dipotong tangan dan kaki mereka secara silang, atau diasingkan dari tempat kediamannya. Yang demikian itu kehinaan bagi mereka di dunia, dan di akhirat mereka mendapat azab yang besar (QS al-Mā'idah/5: 33). ${ }^{27}$

Jika dianalisis QS al-Mā'idah/5: 33 diketahu ada empat hukuman bagi pelaku hirabah, yaitu dibunuh, disalib, dipotong tangan dan kaki, dan dibuang dari tempat kediamannya atau di penjara. Adanya kepastian hukum bahwa Nabi saw tidak melakukan tindak korupsi, sebagaimana yang dilansir oleh ayat tersebut, mengindikasikan bahwa praktek korupsi adalah hal yang terlarang. Dalam kaidah ushul dikatakan bahwa: الأصل فى النهي للتحريم (pada dasarnya, pelarangan adalah untuk mengharamkan). ${ }^{28}$ Jadi dapat dirumuskan bahwa praktek korupsi menurut Alquran adalah "haram" hukumnya.

Selain Alquran, ditemukan pula dalil dari hadis Nabi saw yang meng-haramkan praktek korupsi. Hal ini dapat ditemukan dalam riwayat berikut:

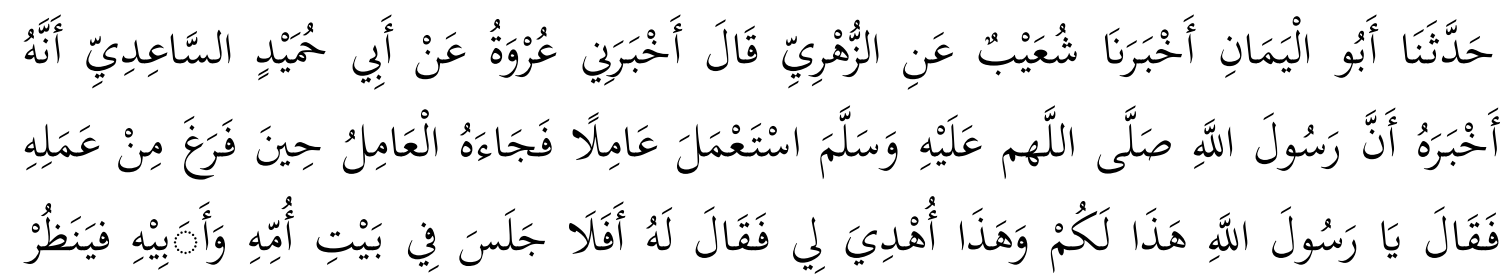

\footnotetext{
${ }^{27}$ Kementerian Agama RI., Ummul Mukminin: Al-Qur'an, 113.

${ }^{28}$ Abdul Hamid Hakim, Ushul Fiqhi (Bandung: Angkasa, 1989), 12.
} 


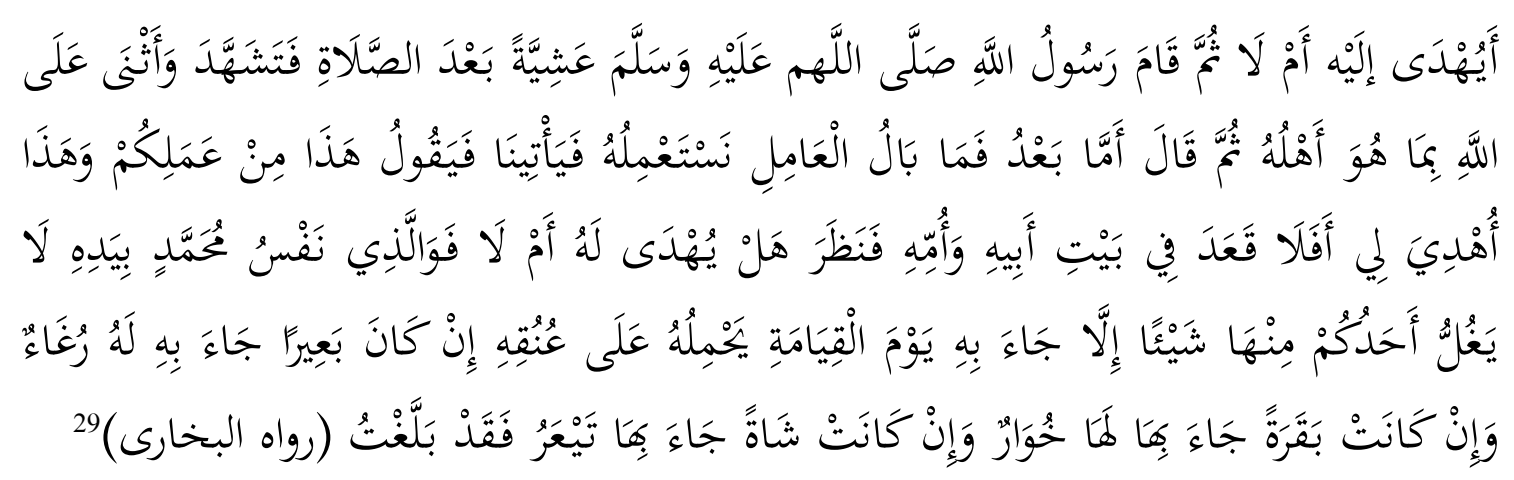

Artinya:

Abū al-Yamān telah memberitakan kepada kami, berkata: Syua'ib telah memberitakan kepada kami, berkata: dari al-Zuhri, berkata; 'Urwah telah memberitakan kepada kami, berkata; dari Humaid al-Saidiy bahwa Rasūlullāh mengangkat seorang pejebat pengumpul zakat (amil). Ketika pejabat telah selesai melaksanakan tugasnya, dia datang kepada Nabi dan berkata: "Ya Rasulullah, ini untuk anda dan ini hadiah yang diberikan orang kepada saya", maka Nabi saw bersabda kepada pejabat itu: "mengapa kamu tidak duduk saja di rumah ayah atau ibumu sehingga kamu dapat melihat apakah dengan kamu juga akan memperoleh hadiah atau tidak?" kemudian pada waktu petang sesudah salat Nabi saw. berdiri (berpidato di hadapan orang banyak). Sesudah membaca kalimat syahadat dan memuji Allah dengan pujian yang Dialah sebagai pemilik pujian itu, Nabi mengatakan." Adapun sesudah itu, bagaimanakah halnya bila seorang pejabat yang kami serahi tugas lalu dia datang melapor kepada kami seraya berkata: "ini adalah hasil tugas yang berasal dari anda. Sedangkan ini adalah (bagian) yang dihadiahkan kepada saya, "mengapa dia tidak duduk saja di rumah ayah atau ibunya, sehingga ia dapat melihat apakah ia akan diberi hadiah (oleh orang) atau tidak. Demi Allah yang diri Muhammad berada dalam genggamanNya tiadalah seseorang dari kalian melakukan sesuatu pengkhianatan, kecuali nanti pada hari kiamat dia akan memikul beban di lehernya. Jika (yang dikorupsi) adalah seekor unta, maka dia datang dengan suara unta. Jika yang dikorupsi adalah seekor sapi, maka orang itu akan datang dengan melenguh seperti sapi; bila (yang dikorupsi) adalah seekor kambing, maka orang itu akan datang dengen mengembek. Sungguh (hal itu) telah kusampaikan kepada kalian (HR alBukhäry).

Secara global dalam hadis tersebut diketahui bahwa Nabi saw. bersabda kepada pejabat-pejabat itu, mengapa kamu tidak duduk saja di rumah bapakmu atau ibumu sehingga kamu dapat melihat, apakah dengan demikian kamu juga akan

${ }^{29}$ Iman Abū 'Abdullāh Ibn al-Mugīrah al-Badizbah al-Bukhāri, Șahīh al-Bukhāri, dalam Mausu'ah al-Hadits asy-Syarif, Al-Ishdar Awwal, Ver. 1.2 (CD. Rom Hadis), Kitab al-Imärah, hadis nomor 6658 . 
memperoleh hadiah atau tidak?. Klausa ini nampaknya memberi indikasi bahwa karena jabatan yang diembang pejabat (amil) itulah sehingga ia diberi hadiah. Dengan kata lain, hadiah itu tidak akan diperolehnya manakalah ia bukan pejabat.

Memahami hadis tersebut, Imam Muslim secara tegas mengatakan keharaman menerima hadiah bagi seorang pejabat. Bahkan diletakkan dalam kitabnya pada judul bab : تحريم هدايا العمال . Menurut Imam al-Nawawy, hadis ini menjelaskan bahwa hadiah bagi seorang pejabat adalah haram dan pengkhianatan. Oleh karena menerima hadiah bagi pejabat itu merupakan penyelewengan dalam kewenangan dan tanggung jawab pejabat. ${ }^{30}$ Sebagaimana yang telah dijelaskan bahwa salah satu makna korupsi adalah "penyelewenan", ini berarti bahwa hadis tersebut berbicara tentang korupsi. Namun modus operandi hadis tersebut adalah terkait dengan masalah hadiah.

Ibn Hajar al-Asqalāni menempatkan kedudukan hukum tahrim atas penerimaan hadiah bagi pejabat karena hal itu merupakan pengkhiatan terhadap jabatan. ${ }^{31}$ Demikian pula keterangan yang disampaikan oleh al-Hafiz Ibn Qayyim bahwa hadis ini merupan penjelasan bahwa hadiah atas para pejabat itu adalah haram dan pengkhianatan. Oleh karena tindakan itu adalah penyelewengan terhadap kekuasaan dan tanggungjawabnya.

Berdasar pada pendapat Ibn Hajar al-Asqalāni dan Ibn Qayyim bahwa menerima hadiah bagi pejabat adalah pengkhiatan, dan salah satu arti korupsi adalah "khianat", praktis bahwa korupsi bagi pejabat adalah hal yang terlarang. Dengan berpegang pada hadis tersebut, dan syarahan yang dikemukakan oleh para muhaddis, maka dapat dirumuskan bahwa keharaman "korupsi" juga ditegaskan dalam hadis. Jadi, tanpa merujuk pada sumber-sumber dasar ijtihad lainnya, misalnya ijma dan qiyas serta selainnya, telah dapat dipahami secara tegas bahwa "korupsi' adalah haram hukumnya.

Para ulama, seperti Imām Abū Hanifah, Mālik, Imam al-Syāfíiy dan al-Laìs, berpendapat bahwa apabila seseorang telah terbukti melakukan tindakan korupsi, maka segala harta kekayaan dari hasil korupsi tersebut harus dikembalikan kepada negara. Di

\footnotetext{
${ }^{30}$ Imām al-Nawāwi, Șahīh Muslim bi Syarh al-Nawāwi, Jilid VI (Bairut: Dār al-Fikr, 1983), 219.

${ }^{31}$ Al-Hāfiz Ibn Hājar al-Asqalāni, Fath al-Bāry bi Syarh Șahīh al-Bukhāri, Juz XV (Bairut: Dār al-Fikr, t.th.), 68 .
} 
samping itu, sang pelaku harus mendapat pelajaran berupa ta'zir (hukuman sesuai ketentuan imam; penguasa). ${ }^{32}$ Bahkan, sebagian ulama berpendapat bahwa tindakan korupsi termasuk salah satu perbuatan dosa besar. ${ }^{33}$

Berdasarkan berbagai pendapat di atas dapat ditegaskan bahwa hukuman yang diberikan kepada koruptor adalah diserahkan kepada imam atau penguasa dalam memilih di antara yang empat hukuman sebagaimana tercantum dalam ayat di atas. Dipilih mana yang bisa memberikan efek jera kepada pelaku dan pelajaran bagi orang lain, termasuk keluarganya. Jika pelaku tindak pidana korupsi bisa lolos dari sanksi potong tangan tidak berarti bahwa perbuatan terkutuk itu akan mendapat sanksi yang ringan. Dalam hukum Islam dikenal sanksi takzir. Pelaku tindak pidana yang tidak dapat dikenakan sanksi had, dapat dikenakan sanksi takzir. Perlu ditegaskan disini bahwa sanksi takzir tidak berarti harus lebih ringan dari sanksi had. Selama tindak pidana tersebut pantas dijatuhi sanksi yang berat seorang hakim atau mujtahid boleh melakukannya.

Abū Zahrah mengemukakan empat syarat yang harus diperhatikan dalam menjatuhkan sanksi takzir, yaitu:

1. Motivasinya adalah memelihara kepentingan yang dijamin oleh syariat Islam, bukan bukan kepentingan atas pertimbangan hawa nafsu.

2. Sanksi yang dijatuhkan harus dapat mengeliminasi kejahatan, membuat jera pelakunya atau minimal mengurangi tindak pidana. Sanksi takzir tidak boleh menimbulkan bahaya yang lebih besar dari kejahatan yang akan diberantas.

3. Sanksi takzir diberlakukan secara adil bagi semua warga.

4. Sanksi takzir itu harus sesuai atau sepadan dengan kejahatan. Tidak boleh terlampau berat, tidak dibenarkan pula jika terlalu ringan. Sanksi yang dijatuhkan harus sesuai dengan dampak yang ditimbulkan oleh kejahatan. ${ }^{34}$

Jika tindak pidana korupsi dianggap sangat berbahaya bagi seluruh bangsa karena dampak negatifnya yang sangat luas, baik dari sudut moral maupun finansial yang sangat merugikan seluruh elemen bangsa, maka sanksinya dapat dijatuhkan

\footnotetext{
${ }^{32}$ Al-Qurțuby, Al-Jami' li Ahkām al-Qur'ān, 260.

${ }^{33}$ Ibid., 258.

${ }^{34}$ Muhammad Abū Zahrah, al-Uqūbah (Kairo: Dār al-Fikri al-Arabiy,1999), 59.
} 
seberat-beratnya. Sanksi tersebut tentu mempertimbangkan empat kriteria yang telah disebutkan terutama kriteria terakhir, yaitu kesepadanan antara sanksi dengan kejahatan.

\section{Hibah dalam Perspektif Hukum Islam}

Secara etimologi kata hibah adalah bentuk masdar dari kata Wahaba, $^{35}$ yang berarti suatu pemberian/ 36 (memberikan kelebihan kepada orang lain walau tanpa materi). Sedangkan hibah secara istilah, jumhur ulama mendefinisikannya sebagai akad yang yang mengakibatkan pemilikan harta tanpa ganti rugi yang dilakukan seseorang dalam keadaan hidup kepada orang lain secara sukarela. Ulama Mazhab Hanbali lebih detail lagi mendefinisikannya, yaitu pemilikan harta dari seseorang kepada orang lain yang mengakibatkan orang yang diberi boleh melakukan tindakan hukum terhadap harta tersebut, baik harta itu tertentu atau tidak, bendanya ada dan bisa diserahkan. Penyerahannya diserahkan ketika pemberi masih hidup tanpa mengharapkan imbalan. ${ }^{37}$

Istilah hibah yang menjadi bagian dari pembendaharaan kata dalam bahasa Indonesia yang berarti pemberian dengan sukarela atau mengalihkan hak atas sesuatu 39 تمليك العين بلا شرط العو اض فى الحال kepada orang lain. ${ }^{38}$ Secara terminologi, hibah berarti (penyerahan hak milik kepada orang lain tanpa adanya syarat pengganti ketika obyek hibah itu diserahkan). Dapat pula dikatakan bahwa hibah itu identik hadiah. ${ }^{40}$

Hibah dalam batasan di atas dapat dipahami bahwa pemaknaannya memiliki kesamaan dengan hadiah, sedekah dan pemberian sukarela lainnya. Hanya saja, hibah merupakan pemberian yang disertai tanpa motif tertentu. Sedangkan hadiah motifnya adalah penyerahan penghormatan dan sedekah motifnya adalah mengharap keredaaan.

\footnotetext{
${ }^{35}$ Ahmad Warson Munawwir, Al-Munawwir: Kamus Arab-Indonesia (Cet. XIV; Yogyakarta: Pustaka Progressif, 1997), 1584.

${ }^{36}$ Abū al-Husayn Ahmad bin Fāris ibn Zakariya, Mu'jam Maqāyis al-Lugah, Juz IV (Cet. II; t.tp.: al-Maktabah al-Manazi', 1980 M/1390 H), 119. Bandingkan dengan 'Abd. Rahmān al-Jaziri, AlFiqh 'alā Mazāhib al-Arba’ah, Juz III (Bairut: Dār al-Kutub al-Ilmiyah, 1990), 254. 1996), 540.

${ }^{37}$ Abdul Azis Dahlan, Ensiklopedi Hukum Islam (Cet. I; Jakarta: Ichtiar Baru Van Hoeve,

${ }^{38}$ W.J.S. Poerwadarminta, Kamus Besar Bahasa Indonesia (Jakarta: Balai Pustaka, 2000), 305.

${ }^{39}$ Al-Jazīiri, al-Fiqh 'alā Mazāhib al-Arba’ah, Juz III, 254.

${ }^{40}$ Ibid., Juz III, 255.
} 
Berdasar keterangan ini, maka hibah adalah pemberian suatu benda secara sukarela dan tanpa imbalan dari seseorang kepada orang lain yang masih hidup untuk dimiliki. Hal ini dapat dipahami bahwa hibah termasuk bagian dari transaksi sosial (mu'amalah), yakni pemindahan hak milik secara permanen yang melibatkan dua pihak (pemberi dan penerima hibah). Perbedaannya dengan jual beli terletak pada 'iwad terhadap harta yang menjadi obyek hibah.

Hibah dalam Islam adalah firman Allah dan juga hadis Nabi yang menganjurkan kepada umat Islam agar berbuat baik dan saling mengasihi kepada sesamanya. Islam menganjurkan agar umatnya suka memberi karena tangan yang di atas lebih baik dari tangan yang di bawah (memberi lebih baik dari pada menerima). Namun pemberian itu harus ikhlas dan tanpa pamrih, tiada tujuan lain kecuali untuk mencari ridha Allah dan mempererat tali persaudaraan.

Menurut Kompilasi Hukum Islam (KHI) dalam Pasal 171 point g "hibah adalah pemberian suatu benda secara sukarela dan tanpa imbalan dari seseorang kepada orang lain yang masih hidup untuk dimiliki" ${ }^{41}$ Dalam Kitab Undang-undang Hukum Perdata Pasal 1666 juga disebutkan bahwa hibah (schenking) adalah "Sesuatu persetujuan dengan mana si penghibah di waktu hidupnya, dengan cuma-cuma dan dengan tidak dapat ditarik kembali, menyerahkan suatu benda guna keperluan si penerima hibah yang menerima penyerahan itu."

Kata "di waktu masih hidup" mengandung arti bahwa perbuatan pemindahan hak milik itu berlaku semasa hidup. Dan bila beralih sudah matinya yang berhak, maka disebut wasiat. Adapun kata "tanpa imbalan atau sukarela," berarti itu semata-mata kehendak sepihak (si pemberi) tanpa mengharapkan apa-apa. Apabila mengharapkan imbalan maka dinamakan jual beli. ${ }^{43}$

Hibah adalah pemberian ketika yang punya harta masih hidup, sedangkan warisan diberikan ketika yang punya harta telah meninggal dunia. Walaupun saat

\footnotetext{
${ }^{41}$ Abdurrahman, Kompilasi Hukum Islam di Indonesia (Cet. I; Jakarta: Akademika Pressindo, 1992), 156.

${ }^{42}$ R. Subekti dan R. Tjitrosudibyo, Kitab Undang-undang Hukum Perdata (Cet. XXV; Jakarta: Pradnya Paramita, 1992), 365.

${ }^{43}$ Amir Syarifudin, Pelaksana Hukum Waris Islam dalam Lingkungan Minangkabau (Jakarta: Gunung Agung, 1995), 252.
} 
pemberiannya berbeda namun keduanya memiliki hubungan yang sangat erat, terutama hibah itu diberikan kepada anak atau ahli waris karena akan menentukan terhadap bagian warisan apabila hibah tersebut tidak ada persetujuan ahli waris atau setidaktidaknya ada ahli waris yang keberatan dengan adanya hibah tersebut. Oleh karenanya sering terjadi sengketa antara ahli waris, satu pihak berpendapat bahwa hibah yang sudah diberikan berbeda dengan warisan, sedangkan pihak lain (ahli waris yang tidak menerima hibah) menyatakan hibah yang sudah diterima merupakan harta warisan yang sudah dibagi. Oleh karenanya ahli waris yang sudah menerima hibah tidak akan mendapat harta warisan lagi.

\section{E. Hadiah dalam Perspektif Hukum Islam}

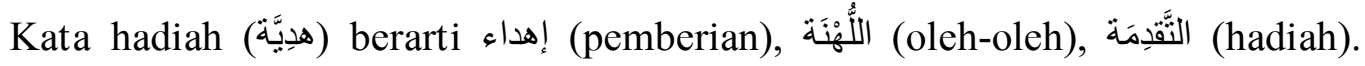
Sebelum menjelasan definisi hadiah, perlu dijelaskan beberapa istilah yang terkadang masih belum dipahami oleh sebagian orang, sehingga sulit dibedakan. Istilah tersebut adalah: hibah, hadiah, dan sedakah. Imām al-Syāfi'ì membagi kebajikan (tabarru') seseorang dengan hartanya kepada dua bentuk. Pertama kebajikan yang berkaitan dengan kematian, yaitu wasiat. Kedua, kebajikan ketika masih hidup yang dibedakannya antara kebajikan murni (mahdhah) dengan waqaf. Kebajikan murni ada tiga macam, yaitu hibah, hadiah, dan sedekah tatawwu'.

Selanjutnya dijelaskan, jika kebajikan harta bertujuan untuk menghormati dan memuliakan seseorang disebut dengan hadiah. Adapun hibah, pada asalnya dilihat dari jenis harta yang diberikan, yaitu kalau yang diberikan itu harta tidak bergerak (tetap). Sedangkan disebut sedekah kalau kebajikan harta itu bertujuan untuk pendekatan diri (taqarrub) kepada Allah dan mengharapkan pahala akhirat. Dengan kata lain, pengertian hadiah adalah pemberian harta kepada orang lain dengan tujuan untuk menghormati (ikram), memuliakan (ta'Zim), mengasihi (tawaddud) dan mencintainya (tahabbub).

Dalil-dalil yang digunakan oleh ulama dalam pembahasan ini pada umumnya berasal dari hadis, antara lain: 


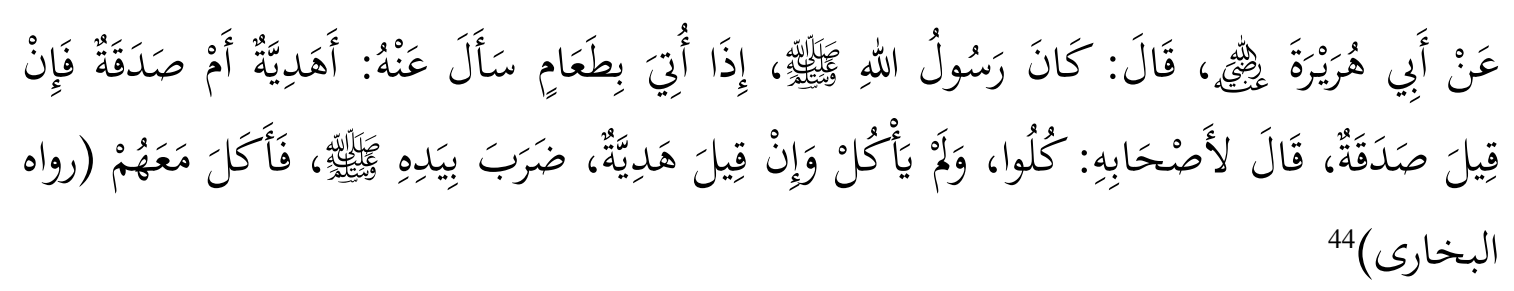

Artinya:

Dari Abū Hurairah, ia berkata, "Rasulullah saw. apabila diberi makanan beliau bertanya: apakah makanan ini hadiah atau sadaqah. Jika dijawab: 'Sadaqah', beliau mengatakan pada para sahabatnya, 'Makanlah oleh kalian', sedangkan beliau tidak memakannya. Akan tetapi bila dijawab: 'Hadiah', maka beliau (Nabi saw) mengambil dengan tangannya lalu makan bersama mereka” (HR al-Bukhāri)

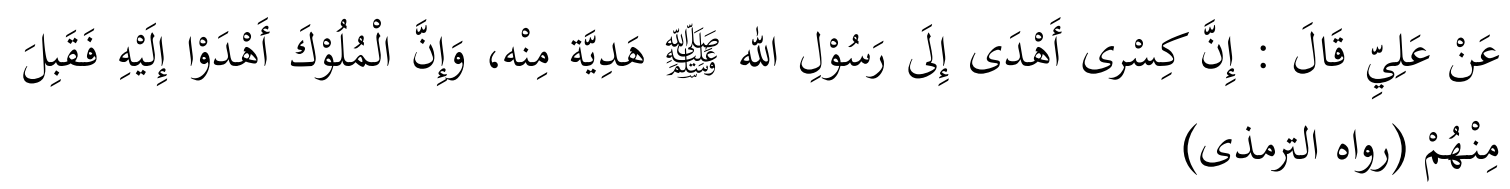

Artinya:

Dari Ali, ia berkata, "Sesungguhnya Kisra memberi hadiah kepada Nabi saw. dan raja-raja lain juga memberi hadiah kepada beliau dan beliau menerima hadiah tersebut dari mereka" (HR al-Tirmiży) ${ }^{45}$

Anjuran saling memberi hadiah, di kalangan ulama telah terjadi ijma', karena Ia memberikan pengaruh yang positif di masyarakat; baik bagi yang memberi maupun yang menerima. Bagi yang memberi, itu sebagai cara melepaskan diri dari sifat bakhil, sarana untuk saling menghormati dan sebagainya. Sedangkan kepada yang diberi, sebagai salah satu bentuk memberi kelapangan terhadapnya, hilangnya kecemburuan dan kecurigaan, bahkan mendatangkan rasa cinta dan persatuan dengan sesama.

Jika dalam menjalankan tugas atau jika terkait dengan tugasnya, seseorang yang memiliki jabatan atau mempunyai wewenang tertentu diberi hadiah oleh pihak lain dengan harapan pejabat tersebut dapat memberi kemudahan tertentu atau memberi keringanan tertentu atas suatu tuntutan, maka hadiah yang demikian dikategorikan sebagai ghulul (korupsi). Hal ini dapat dipahami secara logis, sebab hadiah, tips, bingkisan atau parcel tersebut, sedikit atau banyak mempengaruhi kebijakan dan

\footnotetext{
${ }^{44}$ Al-Bukhāri, Sahīh al-Bukhāri, hadis nomor 2388.

${ }^{45}$ Al-Tirmizy, Sunan al-Tirmizy, hadis nomor 1501.
} 
keputusannya sebagai pejabat/pegawai. Contoh yang paling nyata adalah pegawai/pejabat tingkat atas yang mendapat bingkisan/hadiah tertentu dari bawahannya demi memperoleh keuntungan tertentu. Tindakan demikian dapat merusak sistem yang dilandaskan pada asas keadilan dan kejujuran dan tentu akan merugikan kepentingan umum.

Pemberian sesuatu kepada pegawai/pejabat publik terbagi dalam tiga bagian: Pertama, Pemberian yang diharamkan, baik bagi pemberi maupun penerima. Kaidahnya, pemberian tersebut bertujuan untuk sesuatu yang batil, ataukah pemberian atas sebuah tugas yang memang wajib dilakukan oleh seorang pegawai. Misalnya pemberian kepada pegawai setelah ia menjabat atau diangkat menjadi pegawai pada sebuah instansi. Dengan tujuan mengambil hatinya tanpa hak, baik untuk kepentingan sekarang maupun untuk masa akan datang, yaitu dengan menutup mata terhadap syarat yang ada untuknya, dan atau memalsukan data, atau mengambil hak orang lain, atau mendahulukan pelayanan kepadanya daripada orang yang lebih berhak, atau memenangkan perkaranya, dan sebagainya. Di antara permisalan yang juga tepat dalam permasalahan ini adalah, pemberian yang diberikan oleh perusahaan atau toko kepada pegawainya, agar pegawainya tersebut merubah data yang seharusnya, atau merubah masa berlaku barang, atau mengganti nama perusahaan yang memproduksi, dan sebagainya.

Kedua, pemberian yang terlarang mengambilnya, dan diberi keringanan dalam Memberikannya. Kaidahnya, pemberian yang dilakukan secara terpaksa, karena apa yang menjadi haknya tidak dikerjakan, atau disengaja diperlambat oleh pegawai bersangkutan yang seharusnya memberikan pelayanan. Sebagai misal, pemberian seseorang kepada pegawai atau pejabat, yang ia lakukan karena untuk mengambil kembali haknya, atau untuk menolak kezhaliman terhadap dirinya. Apalagi ia melihat, jika sang pegawai tersebut tidak diberi sesuatu (uang, misalnya), maka ia akan melalaikan, atau memperlambat prosesnya.

Ketiga, pemberian yang diperbolehkan, bahkan dianjurkan memberi dan mengambilnya. Kaidahnya, suatu pemberian dengan tujuan mengharapkan ridha Allah 
swt. untuk memperkuat tali silaturahim atau menjalin ukhuwah Islamiah, dan bukan bertujuan memperoleh keuntungan duniawi.

Terdapat beberapa permasalahan, yang hukumnya masuk dalam bagian ini, sekalipun yang lebih baik bagi pegawai adalah tidak menerima hadiah tersebut, sebagai upaya untuk menjauhkan diri dari tuduhan dan sadd zarí'ah (tindakan preventif) baginya dari pemberian yang haram:

1) Hadiah seseorang yang tidak mempunyai kaitan dengan pekerjaan usahanya). Sebelum orang tersebut menjabat, ia sudah sering juga memberi hadiah, karena hubungan kerabat atau yang lainnya. Pemberian itu tetap tidak bertambah, meskipun yang ia beri sekarang sedang menjabat.

2) Hadiah orang yang tidak biasa memberi hadiah kepada seorang pegawai yang tidak berlaku persaksiannya, seperti qadi bersaksi untuk anaknya, dan hadiah tersebut tidak ada hubungannya dengan usahanya.

3) Hadiah yang telah mendapat izin dari pemerintah atau instansinya.

4) Hadiah atasan kepada bawahannya.

5) Hadiah setelah ia meninggalkan jabatannya.

\section{F. Kesimpulan}

Hukum Islam memamandang bahwa wawasan masyarakat sangat terbatas mengenai masalah sogok dan hadiah. Sebagian masyarakat beranggapan bahwa sogok bukan sebuah kejahatan, tetapi hanya kesalahan kecil. Sebagian lain, walaupun mengetahui bahwa sogok adalah terlarang, namun mereka tidak peduli dengan larangan tersebut. Apalagi karena terpengaruh dengan keuntungan yang didapatkan.

Di pihak lain, masyarakat menganggap sogok itu sebagai hadiah atau tanda terima kasih. Bahkan ada yang beranggapan sebagai uang jasa atas bantuan yang telah diberikan seseorang, sehingga mereka tidak merasakan hal itu sebagai sebuah kesalahan atau pelanggaran apalagi kejahatan. Sudah menjadi realitas betapa banyak risywah terjadi di bidang peradilan yang diberikan untuk memenangkan perkara. Demikian pula di bidang pekerjaan, baik Aparatur Sipil Negara (ASN), swasta, anggota polisi dan tentara, dan bahkan di dunia pendidikan pun hal ini terjadi. 
Perbuatan tersebut tanpa ada perasaan malu dilakukan oleh orang yang mengerti hukum dan aturan.

\section{Daftar Pustaka}

Abdurrahman. Kompilasi Hukum Islam di Indonesia. Cet. I; Jakarta: Akademika Pressindo, 1992.

Alatas, Syed Hussien. Corruption Its Nature, Causes and Functions, terj. Nitwono, Korupsi: Sifat, Sebab dan Fungsi. Jakarta: LP3ES, 1997.

. The Sosiologi of Corruption, terj. Al Ghozie Usman, Sosiologi Korupsi: Sebuah Penjelajahan dengan Data Kontemporer. Jakarta: LP3ES, 1995.

Anwar, Syamsul. "Sejarah Korupsi dan Perlawanan Terhadapnya di Zaman Awal Islam: Perspektif Studi Hadis", Hermenia, Volume 4, Nomor 1, Januari-Juni 2005.

Al-Asqalāni, Al-Hāfiz Ibn Hājar. Fath al-Bāry bi Syarh Sahīh al-Bukhāri, Juz XV. Bairut: Dār al-Fikr, t.th.

Dahlan, Abdul Azis. Ensiklopedi Hukum Islam. Cet. I; Jakarta: Ichtiar Baru Van Hoeve, 1996.

Hakim, Abdul Hamid. Ushul Fiqhi. Bandung: Angkasa, 1989.

Hornby. Oxford Advanced Learner's Dictionary. Oxford: Oxford University Press, 1999.

Ibn Zakariya, Abū al-Husayn Ahmad bin Fāris. Mu'jam Maqāyis al-Lugah, Juz IV. Cet. II; t.tp.: al-Maktabah al-Manazi', 1980 M/1390 H.

Ilyas, Yunahar, dkk., Korupsi dalam Perspektif Agama-Agama. Yogyakarta: Lembaga Penelitian dan Pengembangan Pendidikan, 2004.

Al-Jazìir, Abd. Rahmān. Al-Fiqh 'alā Mazāhib al-Arba'ah, Juz III. Bairut: Dār alKutub al-Ilmiyah, 1990.

Kementerian Agama RI., Ummul Mukminin: Al-Qur'an dan Terjemahan untuk Wanita. Jakarta Selatan: Penerbit Wali, 2010.

Klitgaard, Robert Controlling Corruption, terj. Hermoyo, Membasmi Korupsi, Ed. 2. Cet. II: Jakarta Yayasan Obor Indonesia, 2001.

Klitgaard, Robert, dkk., Penuntun Pemberantasan Korupsi dalam Pemerintahan Daerah, alih bahasa Masri Maris. Jakarta: Yayasan Obor dan Partnership for Government Reform di Indonesia, 2002.

Lopa, Baharuddin. "Korupsi: Sebab-Sebabnya dan Penanggulangannya", Prisma, Nomor 3 Tahun 1996.

Mausu'ah al-Hadits asy-Syarif, Al-Ishdar Awwal, Ver. 1.2 CD. Rom Hadis. 
Munawwir, Ahmad Warson. Al-Munawwir: Kamus Arab-Indonesia. Cet. XIV; Yogyakarta: Pustaka Progressif, 1997.

Muzadi Hasyim, dan Benediktus, Menuju Indonesia Baru. Malang: Bayu Media Publishing, 2004.

Al-Nawāwi, Imām Ṣahīh Muslim bi Syarh al-Nawāwi, Jilid VI. Bairut: Dār al-Fikr, 1983.

Nurdjana, IGM., dkk., Korupsi dan Illegal Logging dalam Sistem Desentralisasi. Yogyakarta: Pustaka Pelajar, 2005.

Poerwadarminta, W.J.S. Kamus Besar Bahasa Indonesia . Jakarta: Balai Pustaka, 2000.

Al-Qurțuby, Abū 'Abdillāh Muhammad bin Ahmad. Al-Jami' li Ahkām al-Qur'ān, Juz IV. Al-Misr: Dār al-Kutub al-Mișriyah, 1967.

Subekti, R., dan R. Tjitrosudibyo, Kitab Undang-undang Hukum Perdata.Cet. XXV; Jakarta: Pradnya Paramita, 1992.

Al-Suyūty, Jalaluddin 'Abdurrahman bin Abì Bakr. Lubāb al-Nuqūl fī Asbāb al-Nuzūl. Bairut: Dār al-Ihyā' al-'Ulūm, t.th.

Syarifudin, Amir. Pelaksana Hukum Waris Islam dalam Lingkungan Minangkabau. Jakarta: Gunung Agung, 1995.

Al-Ṭabari, Abū Ja'far Muhammad bin Jarīr. Jami' al-Bayān 'an Ta'wil Āyāt al-Qur'ān, Juz VI. Bairut: Dār al-Fikr, 1405 H.

Al-Tirmizy, Abū Isa Muhammad bin İsa. Sunan al-Tirmizy. Bairut: Dār al-Kutub alIslamiyyah, 2002.

Al-Wahidy, Asbāb al-Nuzūl. Bairut: Dār Fikr li al-Ṭiba'ah wa al-Nasyr, 1991.

Zahrah, Muhammad Abū. Al-Uqūbah. Kairo: Dār al-Fikri al-Arabiy,1999. 